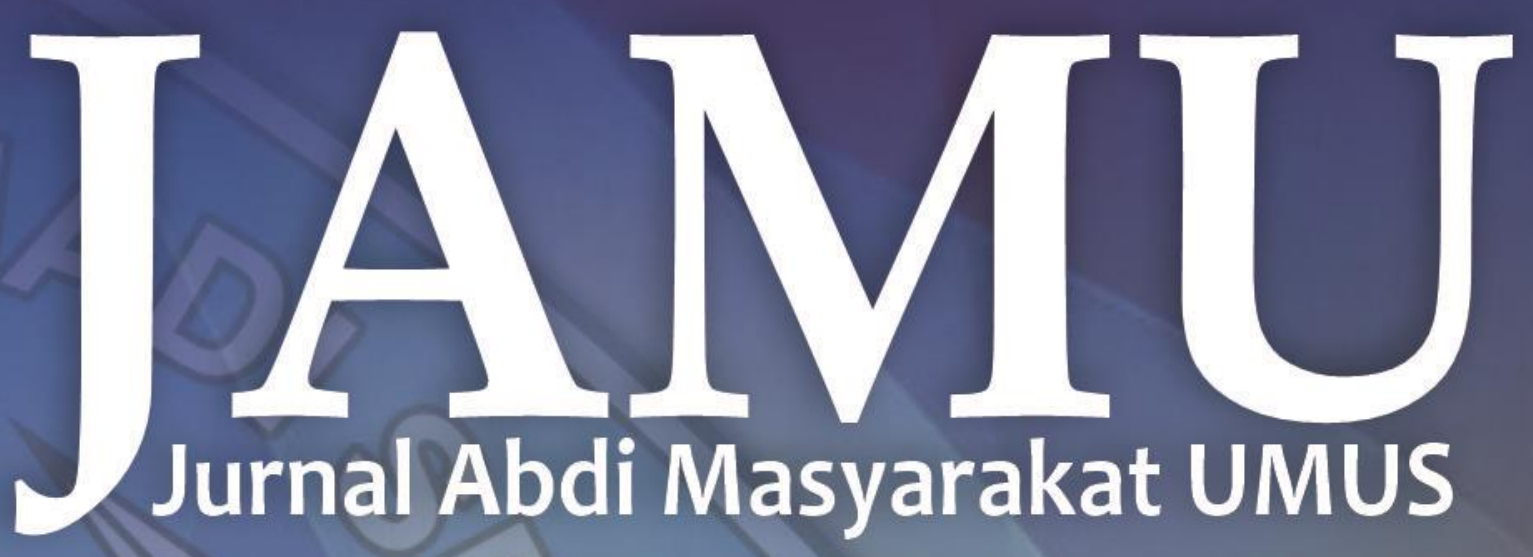




\section{EDITOR IN CHIEF}

Ubaedillah, M.Pd

\section{MANAGING EDITOR}

Harliana, ST., M.Cs

\section{PRINCIPAL CONTACT}

Rifatul Masrikhiyah, S.Tp., M.Si

\section{SUPPORT CONTACT}

Laelia Nurpratiwiningsih, M.Pd

\section{MITRA BESTARI (STAFF AHLI)}

Dr. Roby Setiadi, S.Kom., M.M (Universitas Muhadi Setiabudi, Brebes)

Otong Saeful Bachri, S.Kom., M.Kom (Universitas Muhadi Setiabudi, Brebes)

Dr. Moh. Toharudin, M.Pd (Universitas Muhadi Setiabudi, Brebes) Atikah Mumpuni, M.Pd (Universitas Muhadi Setiabudi, Brebes)

Dr. Heru Ismanto, S.Si., M.Cs (Universitas Musamus Merauke, Papua) Dr. Wuri Wuryandani, M.Pd (Universitas Negeri Yogyakarta)

Dr. Nanik Sulistyani, M.Si., Apt (Universitas Ahmad Dahlan, Yogyakarta)

Dina Rahayuning Pangestuti, S.TP., M.Gizi (Universitas Diponogoro) Jasanta Peranginangin, S.E., M.M (Sekolah Tinggi Pariwisata Sahid Surakarta)

Dr. Lili Karmela Fitriani, S.E., M.Si (Universitas Kuningan, Jawa Barat)

\section{PENANGGUNGJAWAB :}

Rektor Universitas Muhadi Setiabudi Brebes

\section{ALAMAT PENYUNTING:}

LP3M Universitas Muhadi Setiabudi Brebes.

Jalan Pangeran Diponogoro KM 2 Wanasari Brebes - Jawa Tengah 52252. Telp (0283) 6199000 


\section{JAMU}

Jurnal Abdi Masyarakat UMUS

\section{KATA PENGANTAR}

Assalamualaikum Wr, Wb

Puji syukur kehadirat Allah SWT atas anugrahnya sehingga jurnal edisi kali ini dapat terbit. Sebelumnya kami ingin mengucapkan terimakasih banyak kepada dosen/peneliti/profesi yang telah mengirimkan artikelnya kepada dewan redaksi untuk dapat dipublish pada jurnal yang kami kelola. Semua artikel yang masuk kepada dewan redaksi telah melalui proses review oleh mitra bestari dan tim dewan redaksi, segala proses revisi dan redaksional juga telah dilakukan oleh penulis sebelum jurnal ini diterbitkan. Segala bentuk kritik dan saran yang membangun dari pembaca / peneliti yang dikirimkan sangat kami harapkan demi melakukan pembenahan jurnal yang kami kelola. Akhir kata kami menghaturkan terimakasih banyak kepada semua pihak yang sudah terlibat dalam proses penerbitan jurnal ini.

Wassalamualaikum wr wb.

Ketua Dewan Redaksi 


\section{DAFTAR ISI}

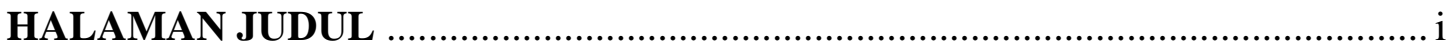

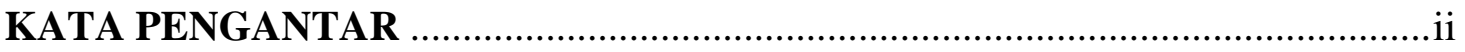

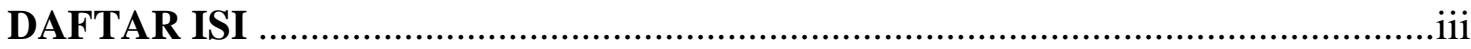

Pemberdayaan Anak Usia Sekolah Dalam Menumbuhkan Nilai Karakter Melalui Strategi Pembiasaan Di PPSA Tegal

Moh. Toharudin ${ }^{1}$, Laelia Nurpratiwiningsih ${ }^{2}$, Gian Fitralisma ${ }^{3}$

${ }^{(1,2)}$ Program Studi Pendidikan Guru Sekolah Dasar, Fakultas Keguruan dan Ilmu Pendidikan Universitas Muhadi Setiabudi

${ }^{3)}$ Program Studi Manajemen, Fakultas Ekonomi dan Bisnis, Universitas Muhadi Setiabudi) $\quad$ 1-7

Menstimulasi Kemampuan Berbicara Pada Anak Usia Dini Berbasis Media Dongeng Agnes Apryliana ${ }^{1)}$, Kiki Purwati ${ }^{2}$

${ }^{(1,2)}$ Program Studi Pendidikan Bahasa dan Sastra Indonesia, Fakultas Keguruan dan Ilmu Pendidikan, Universitas Muhadi Setiabudi)

Pemanfaatan E-Commerce Terhadap Penjualan Kendang Jimbe Blitar Harliana $^{1)}$, Roby Setiadii ${ }^{2}$, Otong Saeful Bachri ${ }^{3)}$, Khalid Iskandar ${ }^{4)}$, Gagas Prasetya ${ }^{5)}$ ${ }^{(1,3,5)}$ Program Studi Teknik Informatika, Fakultas Teknik, Universitas Muhadi Setiabudi ${ }^{2,4)}$ Program Studi Manajemen, Fakultas Ekonomi dan Bisnis, Universitas Muhadi Setiabudi) 15-20

Manajemen Tatakelola BUMDES: Mengelola Pemasaran Produk Andi Yulianto ${ }^{1)}$, Mukson ${ }^{2)}$, Otong Saeful Bachri ${ }^{3)}$, Slamet Bambang Riono ${ }^{4}$, Yenny Ernitawati ${ }^{5)}$ ${ }^{(1,2,4)}$ Program Studi Manajemen, Fakultas Ekonomi dan Bisnis, Universitas Muhadi Setiabudi ${ }^{5)}$ Program Studi Akuntansi, Fakultas Ekonomi dan Bisnis, Universitas Muhadi Setiabudi) ${ }^{3)}$ Program Studi Teknik Informatika, Fakultas Teknik, Universitas Muhadi Setiabudi)

Penggunaan Kartu Huruf dan Peramainan Mencari Kartu Huruf Untuk Peningkatan Pengenalan Huruf

Muhammad Toha ${ }^{1)}$, Ubaedillah ${ }^{2)}$, Farhan Saefudin Wahid ${ }^{3)}$, Laelia Nurpratiwiningsih ${ }^{4)}$, Mohamad Badrun Zaman ${ }^{5}$

${ }^{(1,2)}$ Program Studi Pendidikan Bahasa dan Sastra Indoensia, Fakultas Keguruan dan Ilmu Pendidikan, Universitas Muhadi Setiabudi,

${ }^{3,4)}$ Program Studi Pendidikan Guru Sekolah Dasar, Fakultas Keguruan dan Ilmu Pendidikan, Universitas Muhadi Setiabudi)

${ }^{3)}$ Program Studi Manajemen, Fakultas Ekonomi dan Bisnis, Universitas Muhadi Setiabudi) 
Menumbuhkan Sikap Sadar Lingkungan Bagi Anak Usia Sekolah Dasar

Laelia Nurpratiwiningsih $^{1)}$, Wildan Qosid ${ }^{2)}$, Ubaedillah ${ }^{3)}$

${ }^{(1,2)}$ Program Studi Pendidikan Guru Sekolah Dasar, Fakultas Keguruan dan Ilmu Pendidikan, Universitas Muhadi Setiabudi,

${ }^{(3)}$ Program Studi Pendidikan Bahasa dan Sastra Indonesia, Fakultas Keguruan dan Ilmu Pendidikan, Universitas Muhadi Setiabudi)

$34-41$

Peningkatan Pengetahuan Mengenai Manfaat Pangan Probiotik dan Prebiotik Bagi Kesehatan

Rifatul Masrikhiyah ${ }^{1)}$, Ubaedillah $^{2}$, Rifqi Ferry Balfas ${ }^{3)}$, Susi Yulianingsih ${ }^{4)}$

${ }^{(1,4)}$ Program Studi Ilmu Gizi, Fakultas Kesehatan, Universitas Muhadi Setiabudi,

${ }^{2)}$ Program Studi Pendidikan Bahasa dan Sastra Indonesia, Fakultas Keguruan dan Ilmu Pendidikan, Universitas Muhadi Setiabudi,

${ }^{3)}$ Program Studi Ilmu Gizi, Fakultas Ilmu Kesehatan, Universitas Muhadi Setiabudi)

$42-46$

\section{Pelatihan Wawancara Kerja Dalam Bahasa Inggris Bagi Siswa SMK Menggunakan}

Metode Demonstrasi

Ubaedillah $^{1)}$, Mukson $^{2)}$, Muhamad Toha ${ }^{3)}$, Rifatul Masrikhiyah ${ }^{4)}$, Laelia Nurpratiwiningsih ${ }^{5)}$

${ }^{(1,3)}$ Program Studi Pendidikan Bahasa dan Sastra Indonesia, Fakultas Keguruan dan Ilmu Pendidikan, Universitas Muhadi Setiabudi,

${ }^{2)}$ Program Studi Manajemen, Fakultas Ekonomi dan Bisnis, Universitas Muhadi Setiabudi,

${ }^{4)}$ Program Studi Ilmu Gizi, Fakultas Ilmu Kesehatan, Universitas Muhadi Setiabudi

${ }^{5}$ Program Studi Guru Sekolah Dasar, Fakultas Keguruan dan Ilmu Pendidikan, Universitas Muhadi Setiabudi) 


\title{
MENSTIMULASI KEMAMPUAN BERBICARA PADA ANAK USIA DINI BERBASIS MEDIA DONGENG
}

\author{
Agnes Apryliana ${ }^{1}$, Kiki Purwati ${ }^{2}$ \\ ${ }^{1,2}$ Program Studi Pendidikan Bahasa dan Sastra Indonesia, Fakultas Keguruan dan Ilmu \\ Pendidikan, Universitas Muhadi Setiabudi Brebes, Indonesia \\ e-mail: ${ }^{1}$ agnesapryliana@gmail.com, ${ }^{2}$ kikipurwati@gmail.com
}

\begin{abstract}
The early childhood education is the first spearhead for children to enjoy education.The need for synergy between teachers and students. The language skills possessed by students require stiulation to improve these abilities. The One of language skill that need to be improved namely the ability to speak. The One method that is considered effective is storytelling. Storytelling is active activity carried out by the teacher to stimulate students speaking abilities.Based on the result of dedication that has been done it can be conclude that the method of storytelling can be used teacher to stimulate students speaking ability at the age of 5-6 years.
\end{abstract}

Kata kunci: Berbicara, Mendongeng, PAUD

\section{PENDAHULUAN}

Kondisi pendidikan nasional dari waktu ke waktu mengalami perubahan yang signifikan. Perubahan yang terjadi pada dunia pendidikan tidak lain untuk memperbaiki prses berjalannya pendidikan nasional. Melalui kewenangannya pemerintah selalu memberikan inovasi baru guna tercapainya ujuan pendidikan. Pendidikan pada abad ke-20 ini mengalami banyak tantangan terutapa pada bidang teknologi. Pendidikan nasional dituntut untuk bisa menyajikan system Pendidikan yang mampu melindungi nilai-nilai karakter bangsa dari pengaruh westerenisasi serta Pendidikan bangsa ini dituntut untuk menciptakan budaya literasi bagi masyarakat. Pendidikan usia dini tidak terlepas dari perhatian pemerintah untuk selalu berkembang sesuai dengan kemajuan teknologi. Pendidikan usia dini merupakan upaya pembinaan yang ditunjukan kepada anak yang dilakukan dengan memberikan rangsangan pendidikan untuk membantu pertumbuhan dan perkembangan anak agar memiliki kesiapan untuk memasuki tingkat pendidikan yang lebih tinggi. Berdasarkan Peraturan Menteri Pendidikan dan
Kebudayaan Republik Indonesia Nomor 137 Tahun 2014 Pasal 10, ada enam aspek yang perlu dikembangkan pada anak usia dini. Enam aspek tersebut yaitu moral dab nilai-nilai agama, kognitif, fisik, motorik, bahasa, sosial-emosional, dan seni.

Anak usia prasekolah dipandang sebagai individu yang baru mengenal dunia. Anak belum memahami tata krama, sopan sanun, aturan, norma, etika, dan berbagai hal lainnya yang terkait dengan kehidupan dunia. Usia prasekolah merupakan masa bagi seorang anak unuk belajar berkomunikasi dengan orang lain serta memahaminya. Oleh karena itu, seorang anak memerlukan bimbingan dan stimulus khusus untuk merangsanng kinerja otak untuk memproses berbagai informasi yang disampaikan oleh orang lain.

Pada masa usia dini seluruh kemampuan anak dapat dikembangkan secara maksimal dengan dilakukan secara kontinu atau berkelanjutan dan dilakukan secara opetimal dan salah stu aspek yang dapat dikembangkan adalah aspek bahasa, khususnya dalam keterampilan berbicara. Keterampilan berbahasa menjadi suatu keterampilan yang wajib dimiliki oleh setiap manusia disemua jenjang usia. 
Keterampilan berbahasa terdiri dari keterampilan menyimak, membaca, menulis, dan berbicara.

Keempat keterampilan berbahasa memiliki keterkaitan satu sama lainnya. Setiap orang memiliki kemampuan masingmasing dalam keempat keterampilan berbahasa. Kemampuan berbicara menjadi salah satu kemampuan yang wajib dimiliki oleh peserta didik, terutama pada mereka yang berusia dini. Kemampuan berbicara seseorang dimiliki sejak usia 2 tahun, dan akan berkembang sejalan dengan daya tangkap anak terhadap lingkungan. Kemampuan berbicara seorang anak memerlukan stimulus dan perhatian dari berbagai pihat tidak terkecuali orang tua dan guru. Kemampuan berbicara peserta didik akan sejalan dengan kemampuan bernalar, menerima respon, dan berani untuk menyampaikannya dihadapan umum. Oleh karena itu, telah banyak metode yang digunakan untuk menstimulus peserta didik terutama pada usia dini guna meningkatkan kemampuan berbicara.

Kemampuan Bahasa dipelajari dan diperoleh anak usia dini secara alamiah untuk beradaptasi dengan lingkungan (Nuriani, 2014). Oleh karena itu perlu adanya stimulus untuk merangsang kemampuan berbahasa peserta didik guna meningkatkan kemampuan berbahasa mereka. Salah satu kemampuan berbahasa yang akan ditingkatkan, yaitu kemampuan berbicara.

Berbicara adalah kemampuan mengucapkan bunyi-bunyi artikulasi atau kata-kata untuk mengekspresikan, menyatakan, serta menyampaikan pikiran, gagasan, dan peraasaan (Tarigan, 2008, p.16). Berbicara pada hakikatnya adalah suatu proses komunikasi dengan mempergunakan suara yang dihasilkan oleh alat ucap manusia yang didalamnya terjadi penyampaian pesan dari suatu sumber kepada sumber lain. Dalam berkomunikasi ada yang berperan sebagai pengirim pesan dan penerima pesan.

Dalam mewujudkan keterampilan yang baik pada anak usia dini guru perlu mengetahui kemampuan yang dimiliki pada masing-masing anak. Dengan mengetahui kemampuan yang dimiliki anak, guru akan dapat mengetahui sejauh mana kemampuan yang dimiliki anak yang kemudian akan dengan mudah untuk melakukan pengembangan keterampilan pada anak. Perubahan keterampilan pada anak terjadi sebagai akibat dari latihan yang telah dilakukan, baik secara langsung maupun tidak langsung, serta pemberian pengalaman tertentu.

Pemberian pengalaman tertentu melalui pelatihan harus dilakukan secara sistematis dan terprogram melalui sebuah model pembelajaran. Model pembelajaran yang dilakukan di TK ini merupakan langkah nyata yang dilakukan guna meningkatkan keterampilan berbicara anak secara optimal. Oleh karena itu keterampilan berbicara seorang anak perlu adanya perhatian dan pelatihan yang khusus serta optimal guna meningkatkan kemampuan berbicara.

Anak usia dini merupakan usia emas dimana pada usia ini anak masih meniru dari apa yang dilihat dan didengarnya dan anak akan belajar dari lingkungan. Oleh sebab itu, agar yang dibicarakan oleh anak berupa hal baik maka anak membutuhkan contoh orang disekitarnya yang juga memberikan perilaku positi.

Ownes dalam Kurnia (2009) mengemukakan bahwa anak usia 5-6 tahun memperkaya keterampilan berbicaranya melalui pengulangan. Mereka sering mengulang kosa kata yang baru dan unik sekalipun belum memahami artinya. Pendidikan anak usia dini merupakan Pendidikan yang maling rendah tingkatannya, tetapimemiliki makna yang paling tinggi karena akan melandasi Pendidikan dasar, menengah, dan tinggi sehingga harus dikelola secara professional dan standar (Kurniasih, 2016). Oleh karena itu, perlu adanya perhatian khusus yang perlu diberikan kepada peserta didik pada rentang usia 5-6 tahun.

Dongeng adalah cerita rekaan, khayali yang dianggap tidak benar-benar terjadi, terdapat beberapa aspek didalamnya, yaitu aspek intelektual, aspek kepekaan, kahalusan budi, tapi juga meningkatkan kemampuan otak kanan (Asfandiyar, 2009, p.19). Asfandiyar (2009, p.25) menjelaskan pula bahwa dongeng merupakan salah satu 
cara untuk mengembangkan aspek-aspek kognitif (pengetahuan), afektif (perasaan), social dan aspek konatif (penghayatan) peserta didik. Dongeng memiliki potensi untuk memperkuat imajinasi, memanusiakan individu, meningkatkan simpati, pemahaman, memperkuat nilai dan etika, merangsang proses pemikiran kritis dan kreatif.

Sanchez (2009) menjelaskan bahwa kekuatan utama starategi dongeng adalah menghubungkan rangsangan melalui penggambaran karakter. Dongeng memiliki potensi untuk memperkuat imajinasi, memanusiakan manusia, meningkatkan empati dan pemahaman, memperkuat nilai dan etika, dan merangsang proses pemikiran kritis.

Mendongeng atau bercerita adalah kegiatan yang dapat merangsang kemampuan berpikir kritis dan kreatif peserta didik terutama siswa PAUD. Kegiatan mendongeng menjadi salah satu cara bagi sebagian guru untuk menstimulasi berpikir dan kemampuan berbicara. Didalam kegiatan mendongeng terdapat muatan-muatan mendidik yang tersirat dan tidak menggurui. Metode mendongeng diharapkan mampu menjadi solusi bagi guru untuk dapat memberikan Pendidikan kepada siswa sesuai dengan tujuan pembelajaran yang ingin dicapai.

Sebagai salah satu metode yang dapat digunakan dalam pembelajaran pada program PAUD, dongeng ternyata memiliki banyak manfaat antara lain mengembangkandaya piker dan imajinasi, kemampuan berbicara, serta daya sosialisasi karena melalui dongeng anak dapat belajar mengetahui kelebihan orang lain sehingga merek jadi sportif (Kusmiadi, 2008). Tidak kalah penting bahwa dongeng dapat merupakan salah satu alat komunikatif yang sangat interatif antara pengajar dan peserta didik. Interaksi langsung tersebut memberikan pengaruh dalam pembentukan karakter anak. Selain itu dongen menjadi metode efektif untuk menumbuhkandaya imajinasi pada anak. Burns (2001) menjelaskan bahwa dongeng mempunyai fungsi strategis dalam menumbuhkan sikapsikap positif. Selain itu dongen juga memiliki fungsi menghibur, mendidik, menggugah emosi, imajinasi, dan kreativitas, serta meningkatkan kemampuan berbahasa. Oleh karena itu, diharapkan pendidik mampu dan menguasai keterampilan mendongeng.

Bercerita adalah suatu kegiatan yag dilakukan seseorang secara lisan kepada orang lain dengan alat atau tanpa alat tentang apa yang harus disampaikan dalam bentuk pesan, infomasi atau hanya sebuah dongeng yang menyajikan cerita menyampaikannya dengan menarik (Damaryanti, 2017).

Mendongeng bermanfaat, yaitu (1) mengembangkan fantas, empati, dan berbagai jenis perasaan lainnya. (2) menumbuhkan minat baca. (3) membangun kedekatan dan keharmonisan, dan (4) media pembelajaran. Terdapat berbagai jenis dogeng yang cocok digunakan pengajar, yaitu dongeng tradisional, dongeng futuaristik (modern), dongeng Pendidikan, dongeng sejarah, dan dongeng terapi (Yudha, 2007). Jenis-jenis dongeng tersebut tentu saja cocok digunakan oleh guru untuk menyampaikannya, apabila pendidik mampu memilih tema dan isi dongeng yang dikemas secara menarik, serta disajikan dan disampingkan secara ekspresif dan impresif pada kondisi waktu yang tepat dan sesuai dengan karakteristik, usia, kebutuhan, serta minat peserta didik.

Dalam kegiatan mendongeng memerlukan beberapa teknik. Moeslichatoen (2004) menyebutkan beberapa Teknik mendongeng, yaitu membaca langsung dari buku dongeng, mendongeng menggunakan ilustrasi gambar dari buku, menceritakan dongengsecaa langsung, mendongeng dengan menggunakan papan fanel, mendongeng dengan menggunakan media boneka, dramatisasi suatu dongeng, mendongeg dengan memainkan jari tangan.

Berdasarkan analisis situasi di atas rumusan masalah dalam kegiaatan ini, yaitu bagaimanakah mengiplementasikan metode bercerita/berdongeng dalam menstimulus kemampuan bercrita anak usia dini tahap II di TK Muslimat NU Ketanggungan Kab. Brebes?

Tujuan dari kegiatan ini adalah untuk mengiplementasikan metode bercerita 
dalam menstimulus kemampuan bercerita/berdongeng pada anak usia dini tahap II di TK Muslimat NU Ketanggungan Kab. Brebes

\section{METODE PELAKSANAAN}

Khalayak sasaran Menstimulasi Kemampuan Berbicara Pada Anak Usia Dini Tahap II Dengan Media Dongeng Di TK Muslimat NU Ketanggungan Kab. Brebes. Kegiatan dilaksanakan di TK Muslimat NU 04 Kec. Ketanggungan Brebes dengan jumlah khalayak, yaitu 20 orang. Peserta didik yang terdiri dari usia dini dipilih dengan tujuan untuk meningkatkan dan mestimulus kemampuan berbicara melalui metode berdongeng. Adapun jenis dongeng yang dipili adalah berupa cerita sederhana yang berkaitan dengan dunia anak-anak dan menyimpan pembelajaran moral dan karakter. Adapun yang menjadi narasumber dalam kegiatan ini adalah dosen Program Studi Pendidikan Bahasa dan Sastra Indonesia FKIP UMUS.

Dalam kegiatan pengabdian terfokuskan pada murid-murid TK Muslimat NU 04 Ketanggungan khususnya Kelas Nol Besar yang berjumlah 20 siswa. Metode berdongeng dipilih dengan tujuan sebagai solusi yang dapat digunakan pengajar atau guru untuk memberikan rangsangan kepada peserta didik agar memperlancar kemampuan berbicara. Media berdongeng yang menggunakan buku dongeng diharapkan mampu membuat perserta didik lebih tertarik untuk mengikuti cerita dan memberikan tanggapan terhadap isi cerita.

Luaran yang diharapkan dalam kegiatan Menstimulasi Kemampuan Berbicara Pada Anak Usia Dini Tahap II Dengan Media Dongeng $\quad \mathrm{Di} \quad \mathrm{TK}$ Muslimat NU Ketanggungan Kab. Brebes, yaitu peserta didik diharapkan mampu mengikuti kegiatan pembelajaran dan memberikan umpan balik atau tanggapan terhadap cerita yang telah diceritakan oleh narator (pencerita).

Untuk memecahkan masalah yang telah dirumuskan di atas agar sosialisasi dilakukan secara lancar maka dengan alternatif pemecahan masalah adalah sebagai berikut: sosialisasi dilakukan dengan pendekatan secara berkelompok atau klasikal. Pendekatan klasikal atau kelompok dilakukan dengan tujuan agar berbagai informasi mengenai gerakan literasi dapat tersampaikan secara keseluruhan. Adapun metode yang dilakukan adalah (1) Metode ini dipilih untuk menyampaikan cerita-cerita yang berkaitan dengan dongeng. Metode ini digunakan untuk memberikan informasi sekaligus untuk memberikan rangsangan kepada peserta didik untuk mengikuti cerita. (2) Demonstrasi adalah metode ini dipilih dengan tujuan untuk merangsang pemahaman peserta didik dalam menanggapi dongeng atau cerita yang telah disampaikan. Peserta didik diharapkan mampu menceritak kembali cerita yang telah disampaikan narasumber dengan menggunakan bahasa dan tingkat pemahaman mereka. Tujuan lainnya adalah untuk menstimulus dan melatih keberanian peserta agar mampu berbicara didepan umum.

\section{HASIL DAN PEMBAHASAN}

Pada hakikatnya bahasa Indonesia memiliki kedudukan yang penting, sebagai bahasaa nasional dan bahasa negara. Di samping bahasa Indonesia, terdapat juga bahasa daerah yang digunakan sebagai bahasa ibu oleh siapa saja yang baru pertama kali belajar berbicara. Bahasa daerah dianggap lebih mudah dalam penyampaiannya karena selalu dipergunakan dalam berbagai komunikasi. Berkaitan dengan kemampuan berbicara seseorang kerap akan memulainya dengan cara meniru.

Dari semua empat keterampilan (mendengarkan, berbicara, membaca dan menulis), berbicara terlihat intuitif dan terlihat begitu penting: orang yang menggunakan bahasa disebut sebagai pembicara dalam bahasa tersebut, seolaholah berbicara termasuk semua jenis pengetahuan, dan sebagian besar pembelajar bahasa asing tertarik belajar bahasa supaya dapat berbicara menggunakan bahasa yang dipelajarinya. 
Kegiatan kelas yang mengembangkan kemampuan peserta didik untuk mengekspresikan diri melalui berbicara akan terlihat komponen penting dari kursus bahasa itu. Namun, sulit untuk merancang dan mengelola kegiatan tersebut dari pada kegiatan mendengarkan, membaca dan menulis. Ingat dan bayangkan kembali keberhasilan dalam berbicara di dalam kelas seperti seorang guru atau berpartisipasi layaknya sebagai seorang mahasiswa. Apa karakteristik dari dari aktivitas yang membuat sukses dalam berbicara.

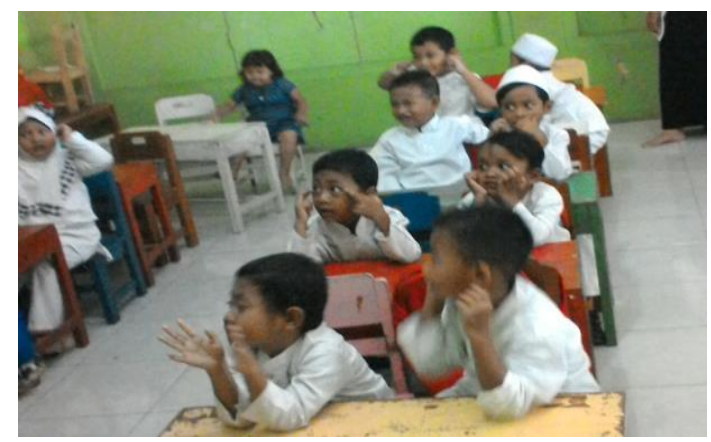

Gambar 1. Kegiatan Saat Di Kelas

Karakteristik keberhasilan dalam berbicara, yakni membiasakan peserta didik untuk banyak berbicara: sebisa mungkin waktu yang dialokasikan untuk kegiatan pembelajaran digunakan untuk belajar berbicara bagi siswa, karena sebagian pembelajaran di kelas gurulah yang paling dominan dalam berbicara. Ikut berpartisipasi lebih dalam pembelajaran : kegiatan ini lebih ditekankan pada kegiatan berdiskusi, semua siswa memiliki kesempatan yang sama untuk ikut berperan serta terutama untuk berbicara, sehingga dapat tercipta iklim diskusi yang baik. Motivasi yang tinggi : Peserta didik yang ingin berbicara: karena mereka tertarik pada topik dan memiliki sesuatu yang baru yang ingin disampaikan, atau karena mereka ingin berkontribusi untuk mencapai tujuan tugas.

Menggunakan bahasa dalam tingkat yang dapat diterima. Peserta didik mengekspresikan diri dalam ucapan-ucapan yang relevan, mudah dipahami satu sama lain, dan tingkat yang dapat diterima oleh akurasi bahasa.
Permasalahan yang terdapat dalam aktivitas berbicara. Penghambatan. Tidak seperti membaca, menulis, dan kegiatan mendengarkan, berbicara memerlukan beberapa derajat paparan secara real-time kepada audiens. Peserta didik sering terhambat saat mencoba untuk mengatakan berbagai hal dalam bahasa asing di kelas mereka khawatir akan membuat kesalahan, takut kritik atau malu kalau pidato mereka tidak menarik.

Tidak ada yang harus dikatakan. Bahkan jika mereka tidak terhambat, permasalah yang muncul dalam diri siswa adalah peserta didik mengeluh bahwa mereka tidak bisa memikirkan sesuatu untuk dikatakan, mereka tidak memiliki motif untuk mengekspresikan diri di luar dirinya. Merasa rendah dan tidak mendapatkan porsi yang sama saat ikud berpartisipasi di dalam kelas. Biasanya hanya satu atau dua peserta yang dapat bicara pada satu waktu sedangkan yang lain tidak ikut berpartisipasi karena merasa tidak mampu/malas. Masalah ini diperparah oleh kecenderungan beberapa peserta didik memiliki sikap untuk mendominasi, sementara peserta yang lain hanya berbicara sangat sedikit atau tidak sama sekali.

$$
\text { Penggunaan bahasa ibu : }
$$

Penggunaan bahasa ibu di kelas di mana semua atau sebagian peserta didiknya memunyai bahasa ibu yang sama, mereka mungkin cenderung untuk menggunakan bahasa ibunya karena merasa lebih mudah dan merasa tidak wajar untuk berbicara satu sama lain dalam bahasa asing. Permasalahan yang muncul jika mereka berbicara dalam kelompok kecil yang tidak mimiliki bahasa ibu yang sama akan menyebabkan komunikasi yang tidak lancar dan terganggu.

Strategi guru untuk mengatasi berbagai permasalahan kaitannya dengan keterampilan berbicara siswa di dalam kelas. Membentuk kelompok kerja. Hal ini meningkatkan jumlah peserta didik untuk dapat bicara dalam jangka waktu yang terbatas dan juga menurunkan hambatan peserta didik yang tidak bersedia untuk berbicara di depan kelas secara penuh. Memang benar bahwa kerja kelompok berarti guru tidak bisa mengawasi semua 
pembicaraan para pelajar, sehingga tidak semua ucapan dapat dikoreksi, dan peserta didik kadang-kadang tergelincir ke dalam bahasa asli mereka. Namun demikian, bahkan dengan mempertimbangkan kesalahan sesekali dan penggunaan bahasa ibu dapat meningkatkan skill peserta didiknya.

Menggunakan kosakata bahasa yang mudah dalam berbagai aktivitas. Secara umum, tingkat bahasa yang dibutuhkan untuk diskusi harus lebih rendah daripada yang digunakan dalam kegiatan belajar mengajar di dalam kelas. Di mana bahasa asing yang dipelajari harus mudah diingat dan diproduksi oleh para peserta didik, sehingga mereka dapat berbicara lancar di kemudian hari.

Memilih dengan cermat topik dan tugas untuk merangsang minat peserta didik. Berikan beberapa instruksi atau pelatihan dalam keterampilan diskusi Jika tugas didasarkan pada diskusi kelompok kemudian termasuk petunjuk tentang partisipasi saat memperkenalkannya. Misalnya, katakan kepada peserta didik untuk memastikan bahwa setiap orang dalam kelompok memberikan kontribusi untuk diskusi, menunjuk seorang ketua untuk setiap kelompok yang akan mengatur partisipasi.

Menjaga siswa untuk tetap berbicara menggunakan bahasa sasaran Mungkin Anda menunjuk salah satu kelompok untuk memonitor, yang tugasnya adalah untuk mengingatkan semua peserta untuk selalu menggunakan bahasa sasaran, dan melaporkan kepada guru seberapa baik peserta dalam kelompok mampu menjaga bahasa yang sedang dipelajari. Berbagai jenis interaksi lisan. Berbicara Interaksional, pada dasarnya hanya terbatas pada kegiatan konvensional. Kegiatan konvensional yang dimaksudkan adalah acara sambutan pada sebuah acara, memulai dan mengakhiri percakapan, permintaan maaf, dan permintaan terima kasih. Berbicara interaksional erat hubungannya dengan budaya. Artinya, bagaimana fungsi interaksional dalam kegiatan berpidato diwujudkan dalam berbagai bahasa tergantung pada budaya dan pengetahuan penguasaan bahasa.
Berbicara luas (panjang lebar) jenis berbicara panjang lebar merupakan salah satu interaksi yang bersifat lebih maju. Kaitannya dengan akademis, peserta didik dimungkinkan untuk mempunyai wawasan (skemata) dalam jenis berbicara ini. Oleh karena itu, jenis interaksi ini perlu dipupuk bahkan dibudidayakan. Berbicara dalam situasi yang bervariasi, menyangkut perasaan, dan hubungan

Pada jenis berbicara ini, peserta didik perlu memahami berbagai macam konteks di atas (situasi yang bervariasi, menyangkut perasaan, dan hubungan). Tujuannya adalah untuk memberikan kesempatan pada peserta didik untuk mencoba dan mengembangkan wawasan kebahasaan melalui simulasi (setidaknya pilihan mereka). Tugas kegiatan seperti diskusi yang konvensional sebenarnya tidak memberikan kesempatan pada peserta didik, karena hanya sekadar memecahkan masalah. Oleh karena itu, dibutuhkan simulasi yang tepat untuk dapat menguasai situasi seperti di atas. Simulasi tersebut disebut role-playing (bermain peran).

Kegiatan PPM yang dilaksanakan dengan cara tatap muka dan praktik berbicara didepan kelas berjalan dengan lancar dan baik. Pertemuan dengan tatap muka dengan metode ceramah dan demonstrasi, dilanjutkan dengan memberikan kesempatan kepada peserta didik untuk menceritakan kembali cerita yang mereka dengar. Kegiatan ini dilaksankaan secara berkala dalam 4 kali pertemuan, yaitu pada tanggal 29 Oktober, 1, 5, 8 November 2018 dari pukul 08.0010.30 WIB. Peserta kegiatan berjumlah 20 orang.

Kegiatan yang diawali dengan ceramah atau bercerita yang dilakukan oleh narasumber guna menarik minat peserta didik untuk ikut serta dalam kegiatan berdongeng. Dari kegiatan awal terlihat adanya antusiasme yang tinggi dari peserta ketika interaksi antara narasumber berjalan lancar dalam memberikan cerita-cerita yang digemari oleh peserta didik. Selama kegiatan aadanya timbal balik yang terjadi antara narasumber sebagai pembawa cerita dengan peserta didik sebagai pendengar dan 
memberikan tanggapan atau respon positif pada setiap pertanyaan yang ditanyakan.

$$
\text { Program pengabdian pada }
$$

masyarakat berupa penerapan metode bercerita untuk meningkatkan stimulus kemampuan berbicara peserta didik usia dini dan meningkatkan kemampuan berpikir kritis ini diharapkan dapat menambah kemampuan, keterampilan, dan lebih percaya diri dalam mengungkapkan pikiran dalam bentuk sederhana. Diharapkan metode ini dapat digunakan oleh guru dalam pembelajaran dikelas guna meningkatnya kemampuan menyimak dan berbicara peserta diddik, serta memberikan rangsangan pada daya pikirnya.

\section{KESIMPULAN}

Program pengabdian pada masyarakat yang dilakukan di TK Muslimat NU 04 Kec. Ketanggungan dapat diselenggarakan dengan baik dan berjalan dengan lancar sesuai dengan rencana kegiatan yang telah disusun meski belum semua peserta menguasai kemampuan berbicara dengan baik dan belum mampu menyampaikan pendapat mereka. Kegiatan ini mendapat sambutan sangat baik, terbukti denga keaktifan peserta dalam mengikuti seluruh rangkaian kegiatan dan tidak meninggalkan tempat sebelum waktu berakhir. Berdasarkan evaluasi yang telah dilakukan dapat diajukan beberapa saran yaitu perlu dilaksanakan kegiatan yang serupa guna menjaga kemampuan peserta didik dalam menyimak dan bercerita. Perlu adanya kerja sama dengan semua pihak guna mewujudkan penggunaan metode bercerita untuk meningkatkan kemampuan peserta didik dalam menyimak dan menyampaikan pendapat mereka.

\section{DAFTAR PUSTAKA}

Asfandiyar, Andi Yudha. (2009). Cara Pintar Mendongeng. Bandung: Mizan

Damaryanti, Pebri, dkk. (2017). Efektivotas Metode Bercerit dengan media Boneka Wayang Terhadap Kemampuan Bercakap-Cakap Anak
Kelompok B Di TK Widya Sesana Sangsit. e-Journal Program Passcasarjana Universitas Pendidikan Ganesha Vol.5. No.3. Diakses pada 2 Desember 2018 dari http://ejournal.undiksha.ac.id/index.php/JJP AUD.

Kurnia, R. (2009). Metodologi Pengembangan Bahasa Anak Usia Dini. Pekanbaru: Cendika Insani.

Kurniasih, Enik Suci. (2016). Effektivitas Metode Bercerita Islami Dalam Meningkatka Kemampuan Berbicara Pada Anak Usia Dini. Yogyakarta: Prosiding Interdisciplinary Postgraduate Ceference I Universitas Muhammadiyah Yogyakarta.

Kusmiadi, Ade, dkk. (2008). Strategi Pembelajaran PAUD Melalui Metode Dongeng Bagi Pendidik PAUD. Jurnal Ilmiah Visi PTK-PNF, Vol. 3, No.2.

Nuriani, Ni Wayan, dkk. (2014). Efektivitas Metode Bercerita Dengan Alat Peraga Tiruan Untuk Meningkatkan Kemampuan Berbahasa dan Minat Belajar Anak Di Kelompok B TK Barunawati. e-Journal Program Passcasarjana Universitas Pendidikan Ganesha Vol.4. Diakses pada 2 Desember 2018 dari http://ejournal.undiksha.ac.id/index.php/JJP AUD.

Sanchez, T, dkk. (2009). Syory-telling as an effective strategy in teaching character education in middle grade social studies. Journal for the liberal arts and sciences, Vol 13, No.2.

Tarigan, H.G. (2008). Berbicara Sebagai Suatu Keterampilan Berbahasa. Bandung: Angkasa

Yudha, A.A. (2007). Cara Pintar Mendongeng. Bandung: Mizan.

Moeslichatoen. (2004). Metode Pengajaran di Taman Kanak-Kanak. Jakarta: Rineka Cipta. 